\title{
Design Strategy Of Football Stadium With Green ArChITECTURE APPROACH In SRAGEN REgENCY
}

\section{STRATEgi Desain Stadion SEPAKBola Dengan Pendekatan Arsitektur HiJau Di KabuPaten Sragen}

\author{
Erpan Nur Saputro ${ }^{1 *}$, Widi Suroto ${ }^{2}$, Sri Yuliani $^{3}$ \\ Program Studi Arsitektur, Fakultas Teknik, Universitas Sebelas Maret ${ }^{1 *}$ \\ Email : ens.saputro@gmail.com* \\ Program Studi Arsitektur, Fakultas Teknik, Universitas Sebelas Maret ${ }^{2}$ \\ Program Studi Arsitektur, Fakultas Teknik, Universitas Sebelas Mare ${ }^{3}$
}

\begin{abstract}
Football is the most popular sport in the world. Football is played in a field inside a building with large scale called Stadium, that can accommodate thousands people in one time. Design strategy of Football Stadium needs certain Handling that would affect energy, water, waste, soil and comfort inside the Stadium and on its surrounding. Sragen has Football club who plays in second league of Indonesian Super League, but it doesn't have a stadium with certain standards as a base for the club. Sragen needs to formulate a strategy in order to design a Football Stadium that can minimalize negative effects to its surroundings, and the most suitable approach is by using Green Architecture. The application of Green Architecture for Football Stadium in Sragen District will also suppot the development of green city in Sragen District. Research method that would be used is exploration method of main idea, data collecting, and data analysing. Design strategy for Football Stadium in Sragen District through green architecture approach is by using solar panels as renewable energy source, natural ventilation, public pedestrian, bicycle lane, lane for disableds, and lane for motor vehicles. The usage of green open space covers up to $40 \%$ of the total area of landscape, and roof material of stadium is translucent membrane.
\end{abstract}

Keywords: Football Stadium, Green Architecture, Sragen Regency

\section{PENDAHULUAN}

Stadion sepakbola adalah wadah kegiatan olahraga sepakbola, dimana cabang olahraga ini merupakan cabang olahraga paling populer di dunia. "Sepakbola menjadi olahraga paling populer di dunia dengan jumlah penggemar sebanyak 3,5 miliar orang. Sepakbola diklaim sebagai olahraga yang paling banyak ditonton di dunia"(Saputro, 2017). Stadion sepakbola sendiri merupakan sebuah wadah kegiatan yang memiliki skala besar dan dapat menampung ribuan orang dalam waktu bersamaan. Dari hal tersebut tentunya stadion sepakbola memerlukan penanganan atau sebuah strategi untuk menanganai dampak yang ditimbulkan pada energi, air, kotoran, tanah dan kenyamanan di stadion dan lingkungan sekitarnya. Maka dari itu dipilihlah penerapan arsitektur hijau. Dimana arsitektur hijau menurut Greenship terbagi menjadi 6 aspek yang dapat dijadikan acuan untuk menelesaikan permasalahn tersebut. 6 aspek tersebut yaitu tepat guna lahan, efisiensi energi, konservasi air, sumber dan siklus material, kwalitas udara dan kenyamanan udara, dan menejemen lingkungan bangunan.

Stadion terletak di kabupaten Sragen. dimana menurut prabowo selaku ketua laskar sukowati. kabupaten Sragen memiliki penduduk pencinta sepakbola yang sudah memiliki 20 kordinator wilayah yang tersebar di seluruh sragen. "saat ini terkumpul 20 koordinator wilayah (korwil) 
yang tersebar di seluruh wilayah kabupaten Sragen. laskar sukowati menurutnya akan memberikan dukungan penuh baik kepada sragen united maupun PSISra untuk berprestasi." (Prabowo, 2017). Selain itu Sragen juga memiliki klub yang bernama sragen united dimana klub ini bermain pada kasta kedua liga super indonesia. yang belum meiliki stadion yang ber standar untuk digunakan sebagai markas. Maka dari itu sudah sekiranya kabupaten sragen membangun stadion dengan menerapkan startegi desain dengan pendekatan arsitektur hijau untuk mewujudkan stadion sepakbola yang meminimalkan dampak negatif terhadap ligkungan. Hal ini juga sejalan dengan program pembangunan kota hijau di kabupaten sragen. seperti kegiatan yang telah dilakukan di edupark gemolong Kabupaten Sragen, Kamis, 20 Oktober 2016 yaitu festival hijau tahun 2016 (LPPL buana asri, 2016).

\section{METODE}

Urutan metode penelitian yang dilakukan yaitu mengexplorasi ide awal, melihat isu yang ada di sekitar. Kemudian menentukan masalah yang ada. setelah itu masalah dirumuskan sehingga didapatkan sebuah rumusan masalah apa saja yang akan di analisis.

Setelah merumuskan masalah berikutnya mencari data pendukung yaitu dengan cara studi literatur, studi lapangan dan studi preseden. Kemudian data yang telah didapat dilakukan analisis untuk menjawab rumusan permasalahan yang telah dibuat. Cara menganalisis data yaitu dengan cara memecahkan masalah menggunakan data yang ada dengan alat bantu studi literatur yang telah di dapatkan.

Dimana data literatur tentang arsitektur hijau menggunakan greenship dari GBCI (Green Building Council Indonesia) ada 6 aspek greenship yaitu Tepat guna lahan, efisiensi energi, konservasi air, sumber dan siklus material, kwalitas udara dan kenyamanan udara, dan menejemen lingkungan banguanan (Saraswati, 2016). Setelah analisis dilakukan maka didapatlah sebuah konsep yang akan menjadi pedoman dalam merancang stadion sepakbola dengan penerapan arsitektur hijau.

\section{HASIL DAN PEMBAHASAN}

Stadion sepakbola yang direncanakan merupakan stadion sepakbola dengan jenis stadion terbuka dengn tipe stadion kelas A, yaitu stadion yang diperuntukan untuk even nasional dan internasional dengan kapasitas 30.000 tempat duduk. Stadion terletak di kabupaten Sragen yaitu sebuah kabupaten yang terletak di privinsi Jawa Tengah dan merupakan kabupaten yang berbatasan langsung dengan provinsi Jawa Timur.

Lokasi stadion terletak di jalan Veteran Taman Sari Sragen, Kroyo, Karangmalang, Kabupaten Sragen, Provinsi Jawa Tengah. Dimana lokasi ini terletak di kecamatan Karangmalang pinggir atau perbatasan dengan kecamatan Sragen sebagai pusat kota kabupaten Sragen. adapun tapak dapt dilihat pada gambar 1 .

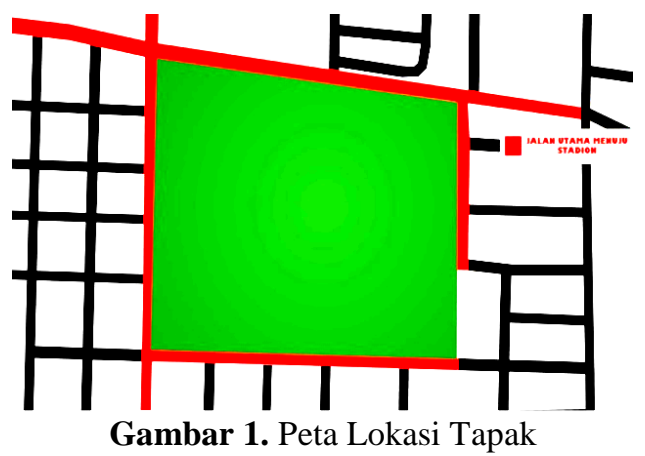

Strategi desain pada stadion sepakbola dengan pendekatan arsitektur hijau didasari oleh 6 aspek greenship. Yaitu :

a. Tepat guna lahan

Strategi desain tepat guna lahan pada stadion sepakbola adalah :

- Area dasar hijau

Strategi desain area dasar hijau pada stadion sepakbola adalah mengacu pada peraturan daerah kabupaten Sragen yang mengatur KDB (Koefisien dasar banguanan) $40 \%$ - 60\% dimana $40 \%$ area hijau sedangkan $60 \%$ adalah area terbangun.

- Pemilihan tapak

Strategi desain pemilihan tapak pada stadion didasakan pada kedekatan tapak dengan fasilitas umum yang dapat mendukung stadion sepakbola. Dari hasil analisis yang dilakukan tapak terpilih berada di jalan veteran taman sari Sragen, kroyo, karangmalang, kabupaten 
Sragen, Provinsi Jawa Tengah. Adapun analisis terhadap tapak dapat dilihat pada gambar 2.

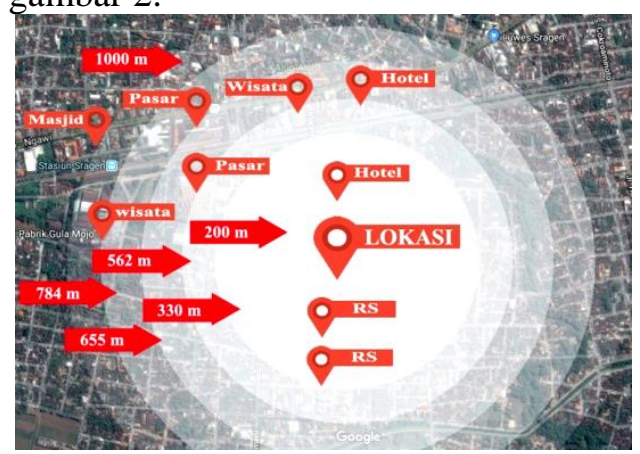

Gambar 2. Analisis Lokasi

Dari gambar 2. menunjukan bahwasanya di radius 1 kilometer terdapat berbagai fasilitas penunjang stadion sepakbola antara lain pusat perbelanjaan, hotel, dan rumah sakit.

- Aksesibilitas komunitas

Aksesibilitas komunitas pada stadion sepakbola dibagi menjadi beberapa zona yaitu zona mobil dan motor, zona pejalan kaki, zona sepeda dan zona difabel. Adapun penerapan aksesibilitas komunitas pada stadion sepakbola seperti pada gambar 3 .

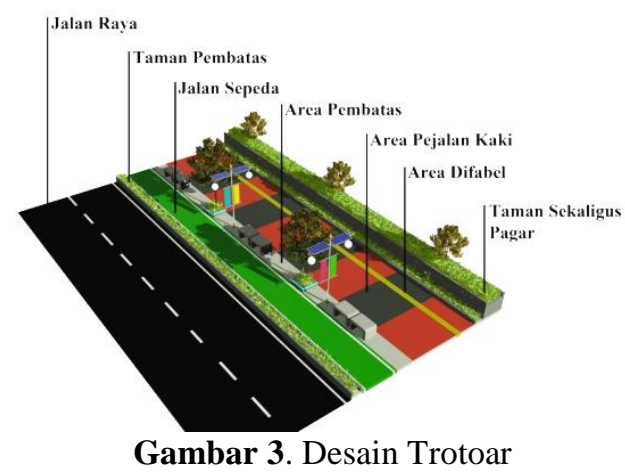

Dari gambar 3. menunjukan strategi desain dari trotoar kawasan stadion sepakbola dibagi menjadi beberapa zona. Desain ini diterapkan pada semua trotoar kawasan stadion sepakbola.

- Transportasi umum dari analisis yang telah dilakukan pada lokasi tapak. Fasilitas transportasi umum yang ada adalah stasiun kereta api yang berjarak $1000 \mathrm{~m}$ dan halte bus yang berjarak $200 \mathrm{~m}$. Seperti yang terlihat pada gambar 5. yang menunjukan lokasi dan jarak fasilitas transportasi umum yang dekat dengan lokasi tapak.

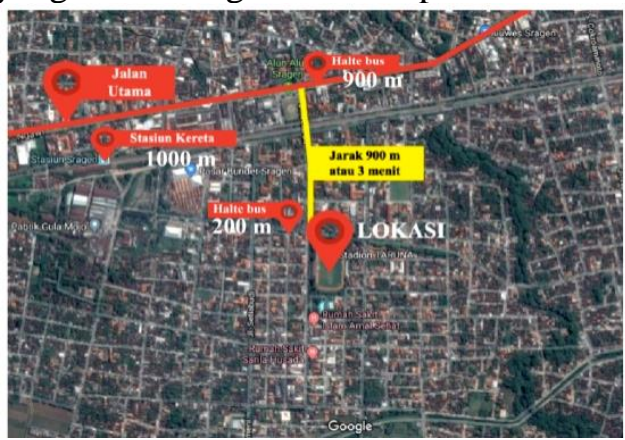

Gambar 5. Analisis Transportasi Umum

Dari gambar 5. menunjukan tapak dekat dengan jaringan transportasi umum yaitu halte dan stasiun kereta api.

- Fasilitas pengguna sepeda

Untuk fasilitas pengguna sepeda pada stadion sepakbola. Di setiap trotoar di sediakan jalur khusus sepeda dan di beberapa titik di letakan parkiran khusus sepeda khususnya di setiap pintu masuk stadion.

- Lansekap pada lahan

Lansekap pada lahan stadion sepakola mengikuti peraturan daerah yaitu $60 \%$ terbangun dan $40 \%$ area hijau. Adapun penerapan penataan dapat dilihat pada gambar 6.

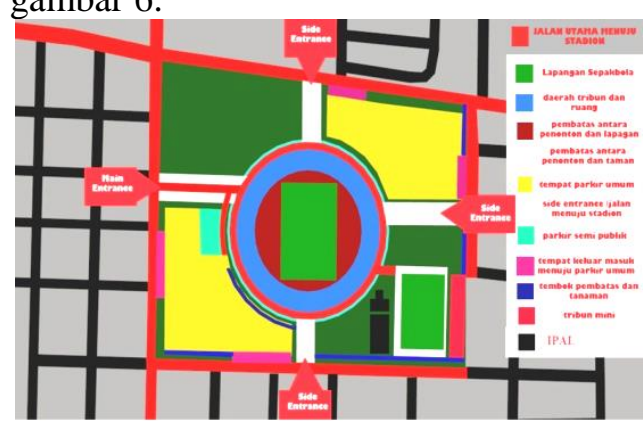

Gambar 6. Penataan Lansekap Pada Tapak

Dari gambar 6. dapat dilihat rencana peletakan masa yang menyisakan $40 \%$ lahan hijau di dalam tapak.

- Iklim mikro

Penarapan pada poin iklim mikro yaitu adaya sirkulasi khusus yang digunaka untuk pejalan kaki yang akan memiliki pelindung atap di beberapa titik trotoar. Hal ini dimaksudkan untuk melindungi pejalan kaki bila terjadi hujan saat 
mereka sedang berjalan kaki pada trotoar. Adapun desain atap pelindung dapat dilihat pada gambar 7 .

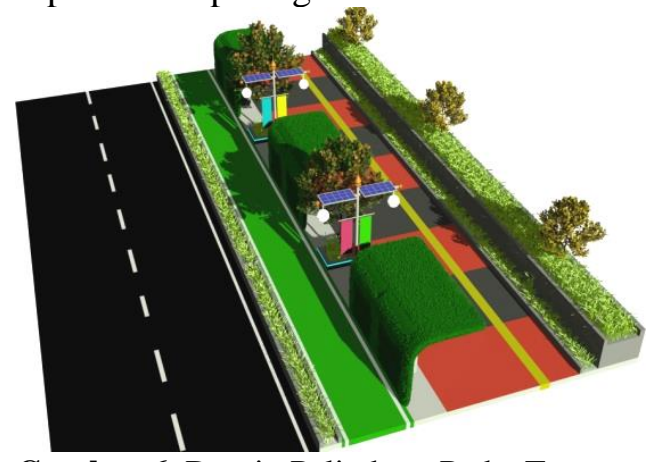

Gambar 6. Desain Pelindung Pada Trotoar

Gambar 6. adalah strategi desain untuk menanggapi masalah pejalan kaki terhadap iklim yang ada yaitu dengan menyediakan tempat berteduh di beberapa titik di sepanjang trotoar.

- Manajemen air limpasan hujan

Manajemen air hujan pada stadion ada beberapa tahap yang akan dilalui sebelum keluar menuju ke jaringan drainase kota. Adapun tahapanya seperti gambar 7.

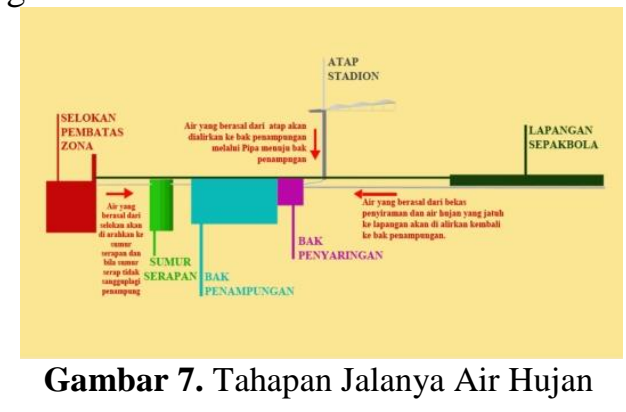

Tahapan sirkulasi air hujan adalah pertama air hujan akan jatuh pada area atapa dan rumput. Dari atap dan lapangan air hujan akan disalurkan menuju bak penampungan air hujan, bila bak penampugan penuh maka air akan mengalir ke sumur peresapan, dan bila sumur peresapan tidak sanggup menampung maka air akan dialirkan ke bak lingkar stadion. bila bak lingkar meluap selanjutnya air akan dibuang menuju saluran drainase kota. Adapun saluran drainase kota dapat dilihat pada gambar 8 .

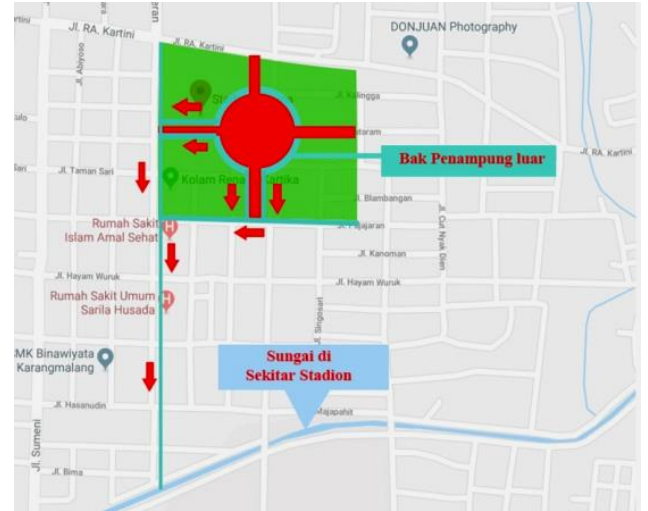

Gambar 8. Analisis Jaringan Air Dari

Tapak Menuju Jaringan Drainase Kota

Gambar 8. menunjukan jaringan air dari tapak menuju jaringan drainase kota.

b. Efisiensi energi

Penerapan efisiensi energi pada stadion sepakbola adalah :

- Langkah Penghematan Energi

Langah penghematan energi yang dilakukan pada stadion sepakbola adalah dengan menggunakan sumber energi terbarukan yaitu panel surya. Adapun bentuk pengaplikasian panel surya pada stadion sepakbola dapat dilihat pada gambar 9 .

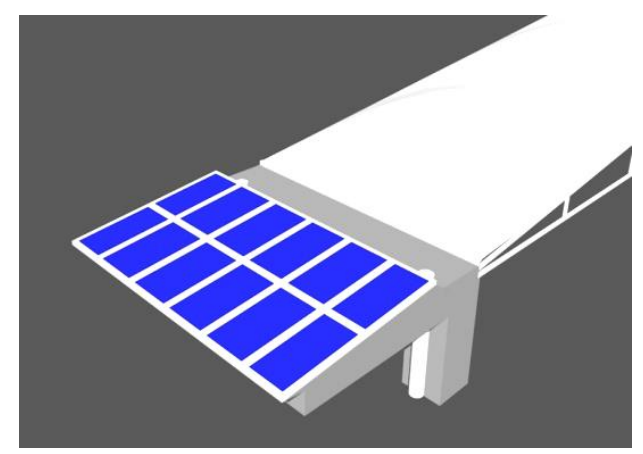

Gambar 9. Pengaplikasian Panel Surya Pada Atap Stadion Dan Lansekap Stadion.

Setelah dilakukan penghitungan pada tahap analisis total energi listrik yang dihasilkan oleh 844 panel surya adalah 2812 watt atau $337 \mathrm{kwh}$ per hari. Dimana dari penghitungan yang dilakukan, kebutuhan listrik stadion setiap harinya adalah $978 \mathrm{kwh}$ bila ada pertandingan. Maka dari panel surya yang terpasang akan menghemat 337 kwh perhari. Dan bila tidak ada pertandingan stadion akan 
mandiri terhadape nergi listrik karena bila tidak ada pertandingan energi listrik yang dibutuhkan adalah 336 kwh setiap harinya dengan catatan tidak menggunakan energi listrik pada siang hari.

Selain menggunakan panel surya stadion akan menggunakan lampu hemat energi baik lampu ruang dan lampu pada lapangan.

\section{- Pencahayaan Alami}

Pencahayaan alami akan diterapkan menyeluruh ke semua ruang yang ada pada stadion sepakbola. Adapun penerapan pencahayaan alami yang ada pada stadion adalah dengan meletakan ruang dekat dengan sumber cahaya. Dan menghindari peletak ruang di dalam ruang. Selain itu menurut (Auliawati, 2015) dalam mendorong penggunaan cahaya alami diperlukan aplikasi selubung banguanan berupa secondary skin, skylight, reflecting pool, dan kaca double glasses. Penerapan green roof dan green wall Adapun hasil analisis seperti pada gambar 10 .

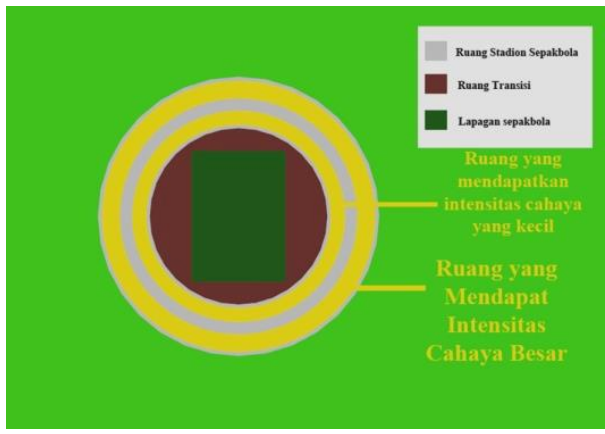

Gambar 10. Analisis Peletakan Ruang Berdasarkan Sumber Cahaya.

Dengan peletakan ruang di atas maka jalur tengah tidak akan mendapatkan cahaya, maka dari itu jalur tengah akan digunakan untuk sirkulasi koridor dengan dibuatkan jalan agar cahaya dapat masuk ke jalur tengah. Adapun pengaplikasian desain seperti pada gambar 11.

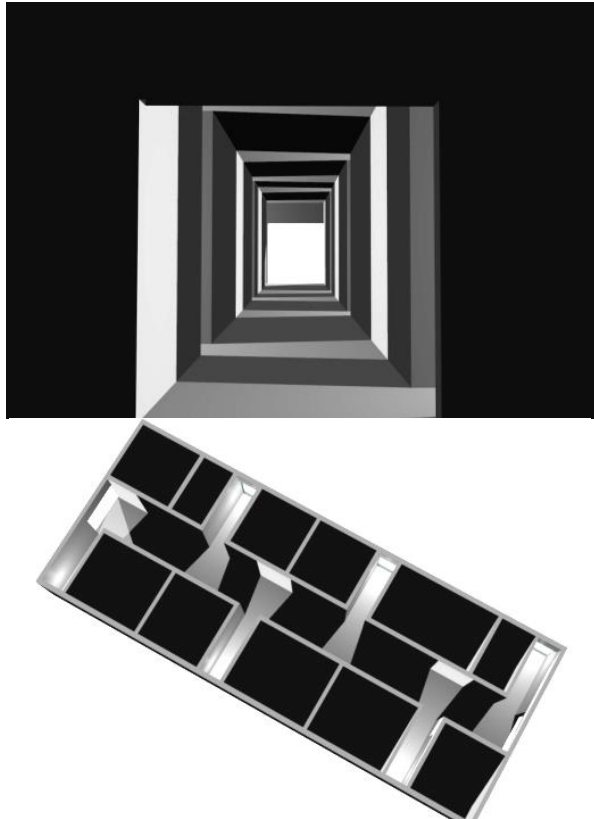

Gambar 11. Penerapan Desain Pada Jalur Tengah Ruang

- Ventilasi

Penerapan ventilasi akan diterapkan pada ruang yang membutuhkannya. khususnya pada kamar mandi, wc, dan koridor.

- Energi Terbarukan Dalam Tapak

Stadion menggunakan energi terbarukan yaitu energi matahari. Dimana stadion menggunakan 1000 panel surya dan 844 diantaranya akan terpasang pada atap stadion sepakbola dan sisanya akan tersebar di seluruh lansekap stadion sepakbola.

c. Konservasi air konservasi air yang diterapkan pada stadion sepakbola adalah :

- Pengurangan penggunaan air kebutuhan air yang paling besar pada stadion adalah air untuk penyiraman rumput yaitu sebesar $542 \mathrm{~m}^{3}$ per bulan. Maka dari itu diperlukan sumber air yang bukan berasal dari PDAM untuk memasoknya. Maka dibuatlah bak penampungan yang akan digunakan untuk keperluan penyiraman rumput dan tanaman pada stadion sepakbola. Sedangkan air PDAM akan digunakan untuk keperluan oprasional stadion sepakbola. Stadion akan menyediakan 8 
tank penampungan air hujan dan 1 kolam yang mengelilingi stadion sepakbola. Dimana setiap tank dapat menampung $100 \mathrm{~m}^{3}$ sehingga total daya tampung tank adalah $800 \mathrm{~m}^{3}$ air. Adapun desain peletakan tank dapat dilihat pada gambar 12.

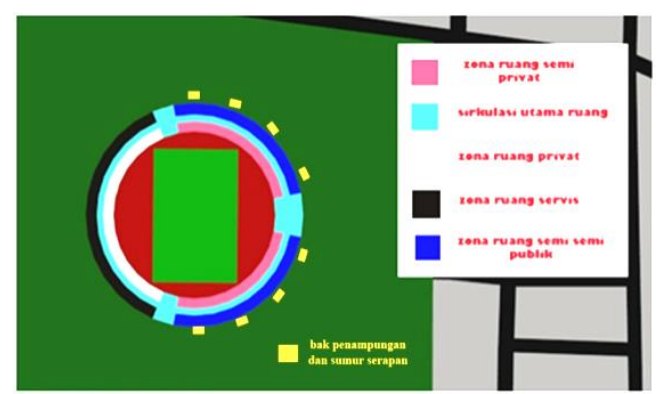

Gambar 12. Peletakan Tank Bawah Tanah Pada Stadion

Tank air akan diletak di bawah tanah yaitu di area lingkar luar stadion. bagian timur karena bagian ini adalah bagian belakng dari stadion yang mana tidak akan menerima beban yang berat seperti bagian depan stadion yang akan dilalui bus truk dan mobil.

- Daur Ulang Air

Stadion sepakbola akan mendaur ulang air hujan dan air bekas pakai wudhu untuk digunakan kembali sebagai air untuk penyiraan tanaman.

- Sumber Air Alternatif

Sumber air alternatif pada stadion adalah air hujan yang akan ditampung dan dimanfaatkan kembali untuk keperluan stadion sepakbola.

- Penampungan Air Hujan

Stadion akan menyediakan wadah penampungan air hujan sebesar $2000 \mathrm{~m}^{3}$ air hujan. dimana $800 \mathrm{~m}^{3}$ air akan ditampung di tangki bawah tanah dan sisanya akan ditampung di kolam yang mengelilingi stadion.

- Efisiensi Penggunaan Air Lansekap

Stadion menyediakan sumur resapan yang tersebar di seluruh lansekap. Sehingga air limpasan yang tidak dapat tertampung sebagian akan masuk ke sumur resapan sebelum keluar menuju drainase kota. d. Sumber dan siklus material

Stadion akan menggunakan material atap berupa membran yang dapat membantu pencahayaan pada tribun pada siang hari. Hal ini dimaksudkan agar tribun stadion pada siang hari tidak mebutuhkan lampu dan pada malam hari tribun dapatterang karena pantulan cahaya dari lapangan stadion.

e. Kwalitas udara dan kenyamanan

- Kendali asap rokok pada lingkungan Stadion sepakbola akan mebuat larangan merokok di dalam stadion sepakbola. Setiap pengunjung yang akan memasuki stadion akan dilakukan pemeriksaan terlebih dahulu hal ini untuk mencegah perbuatan yang tidak diinginkan. Adapun desain pintu masuk stadion sepakbola sebagai berikut :

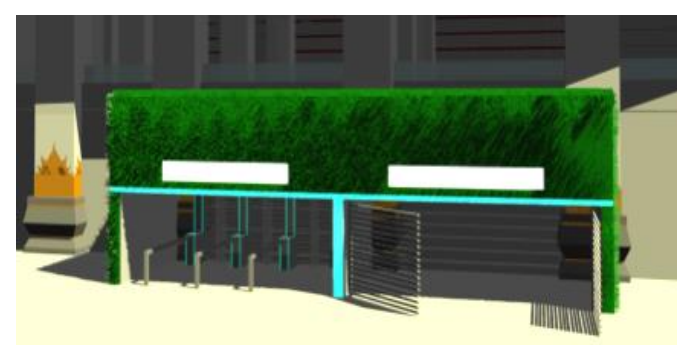

Gambar 13. Desain pintu masuk stadion

Pada pintu masuk stadion akan ada 6 pintu otomatis yang dapat membuka dengan menempelkan tiket pada mesin sensor. Hal ini dilakukan untuk menjaga dan menjaring oknum yang akan membuat keriutan dan tiket ilegal.

- Pemandangan ke luar gedung

Pengunjung stadion sepakbola khususnya penonton akan mendapatkan pemandangan yang bebas ke arah luar karena stadion sepakbola memiliki bentuk yang terbuka khususnya daerah sirkulasi koridor stadion sepakbola. Desain stadion yang menerapkan pemandangan keluar gedung yaitu sebagai berikut : 


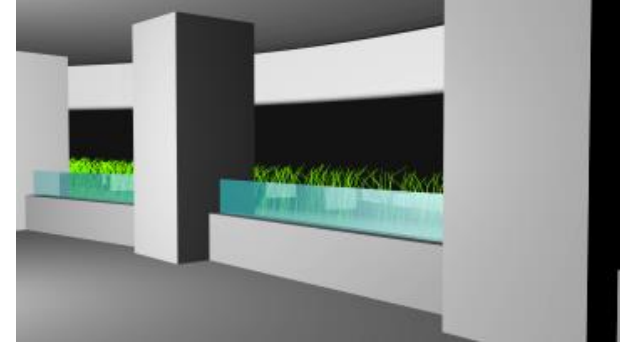

Gambar 14. Desain Bukaan Pada Koridor

Gambar 14. menunjukan area koridor penonton akan dibuka tanpa sekat apapun sehingga cahaya dan udara dapat masuk dengan leluasa dan penonton dapat melihat pemandanga di sekeliling stadion dari atas.

- Kenyamanan visual

Penerapan kenyamanan visual pada stadion dilakukan dengan menganalisis setiap ruang yang ada di stadion dengan kebutuhan akan iluminasi menurut SNI.

Selain itu lapangan juga akan diterangi lampu dengan kekuatan 350 lux. Yang merupakan standar penerangan lapangan pertandingan internasional.

- Tingkat kebisisngan

Analisis tingkat kebisingan dalam ruang adalah sebagai berikut:

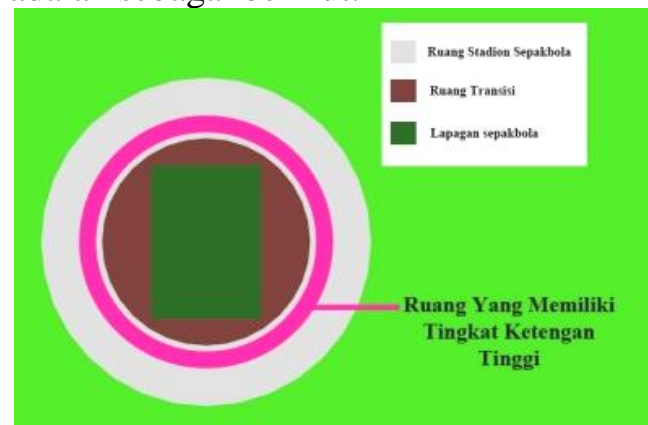

Gambar 15. Daerah Dengan Tingkat Ketengan Yang Tinggi.

Dari gambar 15. maka ruang yang membutuhkan ketenagan aka diletakan pada zona tersebut. dimana zona ini adalah zona yang memiliki tingkat ketenangan dari ekributan di luar stadion sepakbola.

f. Menejemen lingkungan bangunan

- Dasar pengolahan sampah dan limbah Pengolahan sampah akan dipisah menjadi dua bagian organik dan anorganik. Untuk sampah organik akan diolah menjadi pupuk sedangkan anorganik akan dibuang ke penampungan sampah.

Sedangkan untuk penaganan limbah cair akan menggunakan IPAL. IPAL yang akan digunakan adalah IPAL komunil mengingat kapasitas yang akan ditampung besar. Ukuran IPAL pada stadion setelah dilakukan analisis adalah $184 \mathrm{~m}^{3}$ atau $8 \mathrm{~m} \times 23 \mathrm{~m}$.

Dari konsep greenship yang sudah di uraikan di tas maka didapatlah desain stadion sepakbola seperti gambar 16,17,18 di bawah ini :

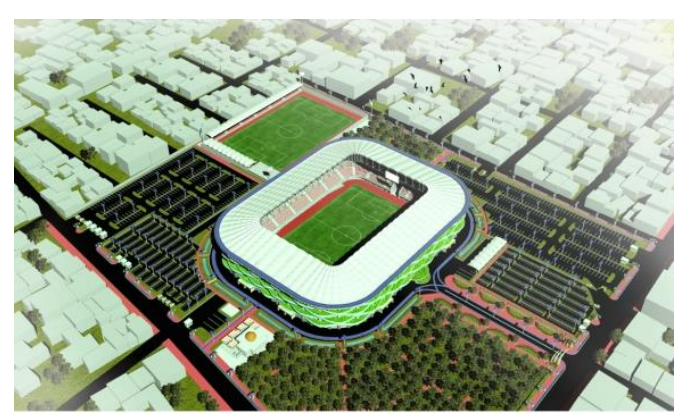

Gambar 16. Perspektif Stadion sepakbola

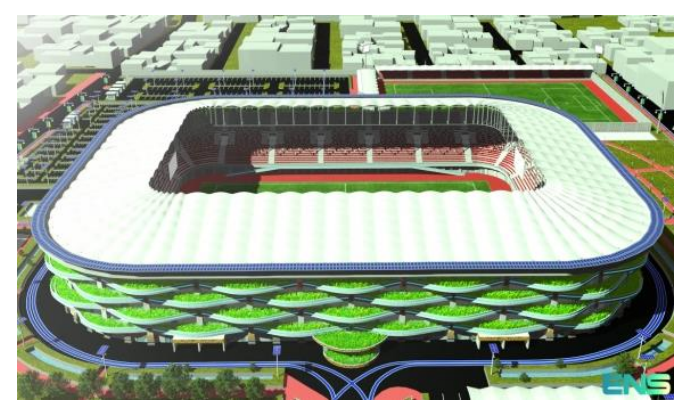

Gambar 17. Perspektif Stadion sepakbola

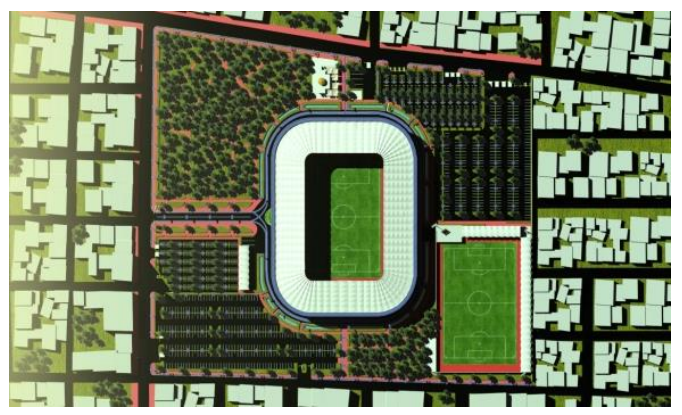

Gambar 18. Tampak atas stadion

Dari gambar 16,17,18 tersebut dapat terliahat strategi desain yang telah digunakan yaitu adanya akses bagi pejalan kaki,difabel,dan kendaraan bermotor serta sepeda. Selain itu terlihat pula penggunaan panel surya yang berada di bagian atap stadion. penggunaan 
bahan atap berupa membran. Dan pengolahan $40 \%$ lahan hijau dari total lahan yang ada.

\section{KESIMPULAN}

Strategi dalam mendesain stadion sepakbola yaitu dengan menggunakan panel surya yang dapat diletakan di bagian atap stadion untuk meringankan beban listrik yang berasal dari PLN.

Jalur khusus untuk kounitas seperti orang yang menggunakan kendaraan bermotor, yang berjalan, yang bersepeda, dan orang yang memiliki kebutuhan khusus yang semunya harus diberikan fasilitas untuk menunjang aktifitasnya.

Penataan kawasan harus menyediakan setidaknya $40 \%$ lahan untuk lahan hijau yang dapat dijadikan sebagi taman. Dan sumber peresapan kawasan.

Penggunaan bahan yang dapat tembus terhadap cahaya seperti pengunaan bahan membran atau kaca sehingga ruang akan hemat energi pada siang hari.

Dengan menerapkan starategi di atas diharapkan dapat menekan dampak negatif pada lingkungan dan fungsi sebagi stadion terpenuhi serta stadion sepakbola yang berskal besar tidak berdampak negatif terhadap lingkungan.

\section{REFERENSI}

Auliawati, R. (2015). BOYOLALI MILK CENTRE DENGAN PENDEKATAN GREEN ARCHITECTURE, 13. Retrieved from https://jurnal.uns.ac.id/Arsitektura

GREEN BUILDING COUNCIL INDONESIA. (2013). GREEN BUILDING COUNCIL INDONESIA PERANGKAT PENILAIAN GREENSHIP GREENSHIP RATING TOOLS. Retrieved from www.gbcindonesia.org

LPPL buana asri. (2016). FORUM KOMUNITAS HIJAU DI SRAGEN PENTING UNTUK PENGEMBANGAN KOTA HIJAU. Retrieved from http://www.lpplbuanaasri.com/forum- komunitas-hijau-di-sragen-pentinguntuk-pengembangan-kota-hijau/

Prabowo, R. seger. (2017). Saat Viking dan The Jakmania Bersatu Dukung Sragen United. Retrieved from http://www.bola.com/indonesia/read/2 896017/saat-viking-dan-the-jakmaniabersatu-dukung-sragen-united

Saputro, D. R. (2017). Sport Time: Ini Dia 5 Olahraga Paling Banyak Disaksikan di Dunia. Retrieved from https://sports.okezone.com/read/2017/ 07/05/43/1729529/sport-time-ini-dia5-olahraga-paling-banyak-disaksikandi-dunia

Saraswati, A. (2016). TAMAN KOMUNITAS DENGAN PENDEKATAN GREEN ARCHITECTURE DI KOTA SOLO, 14. Retrieved from https://jurnal.uns.ac.id/Arsitektura 